\title{
Ankara İlinde Bölge Müdürlüğü Bulunan Sigorta Şirketleri Çalışanlarının Örgütsel Bağlılığının Örgütsel Vatandaşlık Davranışına ve Lider-Üye Etkileşimine Etkisi
} The Effect of Organizational Commitment of Employees of Insurance Companies with Regional Directorates in Ankara on Organizational Citizenship Behavior and LeaderMember Exchange

\section{İbrahim GÖRMÜŞ ${ }^{\text {iD a }}$ Kadir ÖZER (iD a}

a Ankara Hacı Bayram Veli Üniversitesi, Lisansüstü Eğitim Enstitüsü, Ankara, Türkiye. ibrahim.grmus@hotmail.com

a Ankara Hacı Bayram Veli Üniversitesi, Bankacılık ve Sigortacılık Yüksekokulu, Ankara, Türkiye. kadir.ozer@hbv.edu.tr

\begin{tabular}{|c|c|}
\hline MAKALE BİLGİSİ & ÖZET \\
\hline Anahtar Kelimeler: & Amaç - Araştırma kapsamında örgütsel bağllı̆ı̆ın alt boyutları ile örgütsel vatandaşlık davranışı (ÖVD) \\
\hline Örgütsel Bağlllık & $\begin{array}{l}\text { ve lider üye etkileşiminin alt boyutları arasındaki ilişkiler incelenmiş ve bu değişkenler arasındaki genel } \\
\text { ilişki ortaya konulmaya çalışılmıștır. }\end{array}$ \\
\hline Davranışı & Yöntem - Çalışmada nicel araştırma yöntemlerinden ilişkisel tarama yöntemi kullanılmıştır. Araştırmanın \\
\hline Lider-Üye Etkileşimi & yapılabilmesi için oluşturulan ölçekle 02.10.2019 ile 19.12.2019 tarihleri arasında, Ankara ilinde bölge \\
\hline Sigortacılık Sektörü & $\begin{array}{l}\text { müdürlüğü bulunan sigorta şirketlerinde istihdam edilen } 158 \text { kişiden, anket yoluyla toplanan veriler } \\
\text { ışı̆̆ında SPSS programı yardımıyla analiz edilmiştir. }\end{array}$ \\
\hline $\begin{array}{l}\text { Gönderilme Tarihi } 9 \\
\text { Kasım } 2020 \\
\text { Revizyon Tarihi } 28 \text { Aralık } \\
2020 \\
\text { Kabul Tarihi } 5 \text { Mart } 2021\end{array}$ & $\begin{array}{l}\text { Bulgular - Araştırmanın bulguları sonucunda örgütsel bağlllık ile örgütsel vatandaşlık davranışı ve lider- } \\
\text { üye etkileşimi arasında anlamlı bir ilişki tespit edilmiştir. Ulaşlan sonuçlar ise literatürde yer alan diğer } \\
\text { çalışmalarla da desteklenmiştir. Sonuç olarak, sigorta şirketlerinde bağlllık gösteren bireylerin ÖVD } \\
\text { sergilemesi ve lider üye arasındaki etkileşimde etki, sadakat, katkı ve saygı boyutlarını güdümlemesi } \\
\text { beklenmektedir. }\end{array}$ \\
\hline $\begin{array}{l}\text { Makale Kategorisi: } \\
\text { Araştırma Makalesi }\end{array}$ & $\begin{array}{l}\text { Tartışma - Elde edilen sonuçlar dolayısıyla örgütlere bağlılık gösteren çalışanların, motivasyon ve iş } \\
\text { performanslarını olumlu yönde etkileyeceği örgütsel vatandaşlık davranışırgilediği ve etki, sadakat, } \\
\text { katkı ve saygı gibi lider-üye etkileşiminde pozitif yönde bir tutum içerisinde olduğu tespit edilmiştir. Bu } \\
\text { sonuçlardan hareketle hem sigorta şirketleri hem de organizasyonlar, gerek küreselleşme ile gerekse de } \\
\text { küreselleşmenin getirmiş olduğu rekabet şartlarından dolayı kendisine bağlı, örgüt yararına hareket eden } \\
\text { ve kurumsal ast-üst ilişkisinin bilişsel özelliklerini benliğinde barındıran çalşanların örgüt açsından } \\
\text { önemini kavramaya başlamışlarsa da bu yapıdaki bireyleri kaybetmemek amacıyla stratejiler } \\
\text { belirlemeleri, bu ilişkiyi oluşturmak ve korumak amacıyla farklı metotlar uygulamaya başlamaları elzem } \\
\text { bir hale dönüşmüştür.. }\end{array}$ \\
\hline
\end{tabular}

\begin{tabular}{l}
\hline ARTICLE INFO \\
\hline Keywords: \\
Organizational \\
Commitment \\
Organizational \\
Citizenship Behavior \\
Leader-Member Exchange \\
Insurance Sector
\end{tabular}

\section{ABSTRACT}

Purpose - In the scope of the research, the relationships between the sub-dimensions of organizational commitment and the sub-dimensions of organizational citizenship behavior (OCB) and leader-member exchange were examined and the general relationship between these variables was tried to be revealed.

Design/methodology/approach - The comparative survey of method, one of the quantitative research methods, was used in the study. The scale created for the research was analyzed with the help of the SPSS program in the light of the data collected through the survey from 158 people employed in insurance companies located in the regional directorate in Ankara between 02.10.2019 and 19.12.2019.

Received 9 November 2020

Findings - As a result of the study, a significant relationship between organizational commitment and organizational citizenship behavior and leader-member interaction was determined. The results were also supported by other studies in the literature. As a result, individuals who show commitment in insurance companies are expected to exhibit OCB and drive the dimensions of impact, loyalty, contribution and respect in the exchange between the leading-member.

2021

Accepted 5 March 2021

Article Classification:

Research Article

Discussion - Based on these results, both insurance companies and organizations have begun to grasp the importance of employees who are loyal to them, who act in favor of the organization and who have the cognitive characteristics of the corporate subordinate relationship in terms of the organization due to the competition conditions brought about by globalization and globalization, but in order not to lose individuals of this nature. It has become indispensable for them to determine strategies and to start applying different methods in order to create and protect this relationship.

\section{Önerilen Atıf/ Suggested Citation}

Görmüş, İ., Özer, K. (2021). Ankara İlinde Bölge Müdürlügü Bulunan Sigorta Şirketleri Çalışanlarının Örgütsel Bağl1lığının Örgütsel Vatandaşlık Davranışına ve Lider-Üye Etkileşimine Etkisi, İ̧̧letme Araştırmaları Dergisi, 13 (1), 202-215. 


\section{GİRISs}

Günümüzde örgüt kavramının öneminin artması ve örgütsel davranış üzerine yapılan araştırmalar, çalışanların organizasyonlar açısından önemini ortaya koymuş ve firmaların istihdam ettikleri bireylerle etkileşim içerisinde olmaları gerektiği sonucunu da doğurmuştur. Örgütlerin, rekabet ortamının sürekli yükselen olduğu piyasalarda yanlış stratejiler geliştirmemeleri, kar maksimizasyonu sağlayabilmeleri ve varlıklarını ilelebet devam ettirmeleri için iş tanımlarında belirli bir kalıp içerisinde sınırlandırılmış görevlerin ötesinde, davranış sergileyen ve organizasyona gerekliliklerinin üzerinde performans göstererek katkı sağlayan çalışanlara ihtiyaçları vardır. Firmalar kendi görev tanımları doğrultusunda hedeflerine ulaşabilmek amacıyla çalışanlarının bireysel iş performanslarını arttırarak ve bunun sonucunda örgütsel performansını maksimize edebilmek için istihdam ettikleri personellerin örgütsel bağlılığını sağlayarak örgütsel vatandaşlık davranışı sergileyebilmeleri ve karşılıklı saygı, güven ve etkileşim içerisinde olabilmeleri düşüncesiyle çaba sarf etmekte ve birçok şirket içi uygulama gerçekleştirmektedir.

Örgütsel bağllık, çalışanların organizasyona yönelik sadakati ve örgütün başarılı olabilmesi için sergilediği tüm davranışları ifade ederken, örgütsel vatandaşlık davranışı görev tanımının üzerinde emre dayalı olmayan, örgüt yararına davranışları ve lider-üye etkileşimi ise çalışan ile lider arasındaki resmi davranışların aksine; kurum yararına sergilenecek olan resmi davranışların arka planında gelişen güven ve saygı temelinde gerçekleşen kişilerarası davranışları içermektedir. Araştırma çerçevesinde öncelikle bağımlı ve bağımsız değişkenler ile ilgili olan yazın çalışması gerçekleştirilmiş olup, araştırmanın ilk bölümünde örgütsel bağlılık, ikinci bölümünde örgütsel vatandaşlık davranışı ve üçüncü bölümde ise lider-üye etkileşimi ile ilgili bilgilere yer verilmiştir. Daha sonra araştırmanın bağımsız değişkeni olan örgütsel bağlılık ile bağımlı değişkenler olan örgütsel vatandaşlık davranışı ve lider-üye etkileşimi arasındaki daha önce yapılmış olan çalışmalar sonucunda ulaşılan ilişkilere değinilmiştir.

Araştırma kapsamında Ankara ilinde faaliyet gösteren sigorta şirketi bölge müdürlükleri çalışanlarının örgütsel bağlılıklarının, örgütsel vatandaşlık davranışına ve lider-üye etkileşimine etkisi incelenecektir. Bu amaçla Ankara ilinde bölge müdürlüğü bulunan yedi ayrı sigorta şirketinin toplamda 204 çalışanına anket ulaştırılmıştır ve 158 kişiden geri dönüş alınmıştır. Ankete katılan bireylerden elde edilen veriler doğrultusunda analizler yapılmış ve bulgular tespit edilmiştir. Yapılan çalışmalar sonucunda araştırmadan elde edilen bulgularla sonuca varılmış ve sigorta sektöründe yer alan şirketlere yönelik öneriler sunulmuştur.

\section{2. ÖRGÜTSEL BAĞLILIK}

Bağlılık, bireylerin birbirlerine karşı saygı, sevgi ve sadakat göstermeleri anlamına gelmektedir (Tutar, 2016: 224). Çalışanların örgütsel bağlılığı, son zamanlarda hem yöneticiler hem de kurumsal analistler tarafından işe alım süreçlerinde ve çalışanların performansını arttırma nedeniyle araştırma literatüründe fazlaca ilgi görmüştür. Çalışanın bağlılığı, birkaç nedenden dolayı önemlidir. Son bulgulara göre, başlangıçta bağlılığın genellikle iş doyumundan daha iyi bir maliyet öngörücü olduğunu söylemek mümkündür. Dahası, Mowday, Porter ve Dubin (1974) tarafından elde edilen bulgular, son derece kararlı çalışanların daha az kararlı çalışanlardan daha iyi performans gösterebileceğini göstermektedir. Bunun yanısıra, bazı çalışanların bağlılığının bir kuruluşun etkinliği için yararlı bir gösterge temsil edebileceği öne sürülmüştür. Bu bulguların ise hem organizasyon teorisi hem de yönetim uygulaması için önemli etkileri vardır. Örgütsel bağlılık, bir bireyin belirli bir kuruluşta kimliğini ve o organizasyona dahil edilmesinin göreceli bir gücü olarak tanımlanabilir. (1) Kuruluşun amaç ve değerlerine güçlü bir inanç ve kabul, (2) kuruluş adına kayda değer çaba gösterme isteği ve (3) örgütün üyeliğini sürdürmek için güçlü bir arzu şeklinde en az üç faktörle karakterize edilebilir (Steers, 1997: 46).

Allen ve Meyer (1990) tarafından önerilen modelin, en sık analiz edilen model olduğu ve yazarlarının örgütsel bağlılığa yönelik çok boyutlu yaklaşımın geliştirilmesine en büyük katkısı olduğu söylenir. Bu bağlılığa iki ana yaklaşımı bütünleştirmektedir. Birincisi, Mowday vd. (1974)'nin örgütsel bağlllığı, bir bireyin belirli bir kuruluşla ilişkisini ve kimliğini tespit etmenin tutumu şeklinde tanımlamasıdır. İkincisi ise Becker (1960)'in önerisine dayanarak bağlılığın, onu terk etmenin algılanan maliyetleri nedeniyle örgüt içinde kalma eğilimi olarak değerlendirilmesidir. Meyer ve Allen (1984)'in ilk teorik önerisi iki bağlılık bileşeni olan duygusallık ve devamlılık kavramlarını ayırt etmekten ibaretti. Daha sonra, model normatif bağlılık denilen üçüncü bir bileşenle genişletildi. Duygusal bileşen, bir çalışanın kuruma duygusal bağlllığı ve onunla özdeşleşme anlamına gelir. Duygusal bağlılı̆̆ güçlü olan kişiler bunu yapmak istedikleri için organizasyonda 
istihdamlarına devam ederler. Duygusal bağl1lık kavramı ise, bağlılık biçiminin en temel yönü olması nedeniyle bu bileşenin geliştirilmesinde rol oynayan tüm faktörlerin güçlü pozitif duygulara eşlik ettiği inancıyla şekillendirilmiştir. Bununla birlikte, Meyer ve Herscovitz (2001) diğer araştırmacılardan farklı olarak; onu yalnızca bireyin duygusal bir şartı olarak ele almayıp ancak bunun bağlılık biçiminin önemli bir bilişsel unsuru olduğuna inanmaktadırlar. Devamlılık bileşeni, kurumdan vazgeçme ile bağlantılı maliyetlerin farkındalı̆̆ıdır. Organizasyonla temel bağları devamlılık bileşenine dayanan çalışanlar, ihtiyaç duydukları durumlarda organizasyonda kalırlar. Ancak, normatif bağlllık bileşeni, organizasyonda kalmak için ahlaki bir görev duygusudur. Normatif bağlılığı yüksek olan kişiler, bunu yapmaları gerektiğini düşünürler. Dolayısıyla bağllık, bir bireyi eylem sürecine bağlayan güçtür. Bu güç, farklı biçimlerde olabilen arzu, algılanan maliyet veya eylem sürecinin devamlılık maliyeti gibi bir zihin durumu olarak deneyimlenir. Bu akıl halleri, bağlllık kavramının altında yatan ayırt edici unsurlarla yansıtılmaktadır. Bu ise her bir çalışanın gücünü ölçebilme ve ortaklaşa bireyin "bağlılık profilini" yansitabilme olasılığı sağlar (Wolowska, 2014: 129-130).

\section{3. ÖRGÜTSEL VATANDAŞLIK DAVRANIŞI}

Son yıllarda örgütsel vatandaşlık davranışı (ÖVD) birçok endüstriyel-örgütsel psikoloğun dikkatini çekmiştir. Hatta örgütsel vatandaşlık davranışına olan ilgi en az Katz (1964)'a kadar dayandığı bilinmektedir. Daha sonra Smith, Organ ve Near (1983) tarafından daha açık hale getirilen Katz tezi, kuruluşların başarılı bir şekilde çalışması için çalışanlarının, işlerini asgari resmi ve belirtilen teknik yönlerinden daha fazlasını yapmaya istekli olmaları gerektiğiydi (Rioux ve Penner, 2001: 1306). Örgütsel vatandaşlık davranışı ifadesi ilk olarak Smith, Organ ve Near tarafından 1983 yılında yaptıkları çalışmalarda kullanılmıştır. Organ vd., bu ifadeyi Chester Barnard (1938)' 1 iş̧birliğine istekli ifadesine ve Daniel Katz (1964)'ın yenilikçi ve kendiliğinden olan davranış ifadesine dayanarak geliştirmiştir. Daniel Katz'ın çalışması bugüne kadar tüm ÖVD çalışmaları için bir temel haline gelmiştir. Hatta Katz'dan etkilenmeyen ÖVD araştırmasının olduğunu söylemek mümkün değildir. Katz ve Kahn (1966)'a göre, örgütlerin etkili olabilmesi için üç ana üye niteliğine ihtiyaçları vardır. Öncelikle, üyeler sempatik olmalı ve insanları organizasyon içinde tutmalıdır. İkincisi, kuruluştaki üyelerin olumlu davranışlar göstermesi ve asgari niteliksel ve niceliksel kriterleri karşılaması gerekir. Üçüncüsü, organizasyondaki insanlar rollerinin gerektirdiği şeyden daha fazlasını gerçekleştirmeli ve örgütsel görevlerini ve amaçlarını yerine getirmeye çalışmalıdırlar. ÖVD'nin tanımında ise bu niteliklerin asıl bileşenler olduğu görmek mümkündür. Örgütsel vatandaşlık davranışı literatürde detaylı ve çeşitli şekillerde tanımlanmıştır. Bununla birlikte, tüm tanımların merkezi; görev veya iş için kritik olmasa da, örgütsel işleyişi kolaylaştırmak amacıyla çalışanların davranışları olduğu fikridir. Bu nedenle, ÖVD örnekleri iş arkadaşlarına yardım etmek, zorunlu olmayan fonksiyonlara katılmak vb. gibi aktiviteleri içerir. Bu yüzden çalışanların örgütsel vatandaşlık davranışı sergileyip sergilemediklerinin araştırılmasının büyük bir ilgi görmesi şaşırtıcı olarak görülmemelidir (Lee ve Allen, 2002: 132).

Literatürde yaklaşık otuz farklı ÖVD tipi vardır; bunlar; (1) özgecilik, (2) genel uygunluk (aynı zamanda literatürde "vicdan" olarak da adlandırılır), (3) sivil erdem, (4) sportmenlik ve (5) nezaket şeklinde beş ana grupta düzenlenmiştir. Fedakarlık, örgütsel sorunları ve görevleri olan diğer insanlara yardım etme isteğidir. Vicdan, insanların organizasyonda gerekenden fazla örgütsel kuralları kabul edip benimsemelerini ifade etmektedir. Bu davranış, hiç kimsenin personeli izlememesi veya denetlememesi durumunda bile, personelin kurallara uyma konusuna titizlikle bağlı kalmasıyla sonuçlanmaktadır. Nezaket, örgütsel sorunların yaşanmasını önlemek için kullanılan davranışı ima etmektedir. Sportmenlik, tatmin edici olmayan koşullar ve hoşlanılmayan durumlar için tolerans gösterme davranışıdır. Sivil erdem, çalışanların yönetime aktif olarak katılmaya istekli olma, tehditleri ve fırsatları izleme ve kuruluşun çıkarları için ek görevler yapma gibi örgütsel ilişkiler konusundaki durumları içerir. Ayrıca, çalışanların ÖVD'si işin çekiciliğini artırabilir ve kuruluşların bu şekilde daha yetenekli ve iyi eğitimli insanları işe almalarını sağlayabilir, böylece kuruluşun performansı daha istikrarlı olacaktır (Tongur, 2011: 12-14).

\section{LIDER-ÜYE ETKILEŞIMI}

Geleneksel olarak liderlik araştırmaları, liderlerin çalışanlara karşı eşit şekilde davrandığını varsayarak liderin astlara karşı "tipik" veya "ortalama" davranışına odaklanmışlardır. Üyeler arasındaki bireysel farklılıklar da ciddi olarak düşünülmemiş; liderlerin ortalama alt algısındaki sapmalar ise sıklıkla hata varyansı olarak ele alınmıştır. Daha sonra, Haga ve arkadaşları (1975) ise "Ortalama Liderlik Tarzı (ALS)" yaklaşımı olarak adlandırılan bu uygulamaya itiraz etmiş ve Lider Üye Değişimi (LMX) modeli ile liderlerin astlara karşı 
muamelelerinde ayrımcılık yaptığını ve rol tanımlarını önemli ölçüde etkilediğini savunmuşlardır. Bu rol tanımı, yöneticinin hem kişisel hem de konumsal durumunun, üyelerin örgütsel olarak değerli katkıları ile değiştirildiği bir müzakere sürecinden ortaya çıkmaktadır. "Lider-üye etkileşimi", üyelerin ihtiyaçları ve katkıları bakımından farklılık göstermesi ve bir liderin zamanı ve kaynakları sınırlı olması nedeniyle kaliteye göre değişiklik gösterecektir.

Jacobs (1971)'un liderlik ve otorite arasındaki önemli ayrımına dayanarak, lider üye değişimlerinin kalitesi, "grup içi" ve "grup dışı" olmak üzere iki temel kategoriye ayrılmıştır. Bir "grup içi" ilişki, yüksek güven, karşılıklı etki, destek ve resmi / gayri resmi ödüller ile karakterize edilir. Buna karşılık, bir "grup dışı" ilişki, resmi otorite kullanımı, düşük güven, destek ve ödüller ile karakterize edilir. Grup içi etkileşimler, daha fazla lider dikkati, destek ve duyarlılık, daha fazla üye memnuniyeti ve daha düşük maliyet, daha iyi üye performansı ve iş problemlerinin ciddiyeti konusunda grup dişı etkileşimden daha fazla anlaşma ile ilişkilendirilmiştir (Fairhurst ve Chandler, 1989: 215). Dienesch ve Liden (1986), lider üye etkileşiminin karşılıklılık yapısına göre gelişmesini önermektedir. Onlara göre karşılıklılığın üç boyutu bulunmaktadır. Bunlar etkileşim, sadakat ve etki için algılanan katkılardır. Bu üç boyutun lider üye etkileşimini etkilemesi daha muhtemel olup; etkileşim ve sadakati geliştirmek zaman gerektirmektedir. Etki burada, liderin ve üyenin birbirleri için kişilerarası çekimine dayanan karşlıklı sevgisi olarak tanımlanmaktadır (Dockery ve Steiner, 1990: 397).

LMX teorisinin evrimini yaklaşık 30 yıl boyunca özetleyen Graen ve Uhl-Bien (1995) yakın zamanda LMX teorisinin dört aşamadan geçtiğini, her aşamanın ise ondan önceki aşama üzerine (LMX sürecinin teorik olarak açıklanması açısından) inşa edildiğini öne sürdü. Birinci aşama araştırması, liderlerin astlarıyla farklı ilişkiler geliştirdiğini, liderlerin çalışma birimlerinde ("Ortalama Liderlik Tarzı" veya ALS modeli olarak adlandırılan) tüm astlara karşı tutarlı bir davranış sergilediğini varsayan liderliğe hakim yaklaşımdan ayrıldığını saptamıştır. İkinci aşama, liderin çalışma biriminde astları arasındaki farklılık ilişkilerine odaklanmış ve LMX yapısını çevreleyen nomolojik ağın açıklanması sağlamıştır; LMX araştırmalarının çoğunluğu ise bu iki aşamaya göre gerçekleştirilmiştir. Liderlik Yapma Modeli ise LMX araştırmasını değiştirerek aşamayı üçe yükseltmiş ve vurguyu liderlerin astları farklılaştırmasından, "her biriyle ortaklık geliştirmek için her bir kişi ile birebir nasıl çalışabileceklerini" belirmiştir. Son aşama ise ikiden daha büyük ortaklıklara kadar kapsamı genişletmiş, organizasyonel sistem içinde ve dışında ikili ilişkilerin nasıl düzenlendiğini araştırmıştır (Schriesheim, Castro ve Cogliser, 1999: 66-76).

\section{DEĞİŞKENLER ARASI İLIŞKİLER}

\section{1. Örgütsel Bağhlık ile Örgütsel Vatandaşlık Davranışı Arasındaki İlişki}

Araştırmada ele aldığımız bağımlı değişken örgütsel bağlılık ile bağımsız değişken örgütsel vatandaşlık davranışı arasındaki ilişkiyi ele almadan önce, iki değişken arasında yapılmış geçmiş çalışmalara göz atmak istersek; Bogler ve Somech (2004)'ün İsrail'de, 25'i ortaokul, 27'si lise olmak üzere toplam 983 öğretmen üzerinde yaptığı araştırmada, örgütsel bağlılık ile örgütsel vatandaşlık davranışı arasında pozitif bir ilişki olduğu sonucuna ulaşılmıştır. Benzer şekilde, Yorgancıŏ̆lu vd. (2019)'nin Eskişehir'de faaliyet gösteren kamu, özel ve üniversite hastanesinde çalı̧̧makta olan toplam 854 kişi üzerinde basit rastgele örnekleme yöntemi ile yapmış olduğu araştırmada örgütsel vatandaşlık davranışı arasında anlamlı bir ilişki olduğu sonucuna ulaşılmıştır. Yorulmaz ve Çelik (2016) tarafından İstanbul'un Bağcılar ilçesindeki ilkokullarda istihdam edilen 309 sınıf öğretmeni üzerinde yapılan çalışma sonucunda örgütsel bağlllık ile örgütsel vatandaşlık davranışı algıları arasında pozitif, yine aynı şekilde Ibrahim ve Aslinda (2013)'nın 18 çalışma biriminde görevlendirilen ve toplamda 176 kişiden oluşan PT Telkom Makassar şirketi çalışanları üzerinde yaptığı araştırmada ise örgütsel bağlılığın, örgütsel vatandaşlık davranışı ile olumlu ve önemli ölçüde ilişkili olduğu sonucuna varılmıştır.

\section{2. Örgütsel Bağlılık ile Lider-Üye Etkileşimi Arasındaki İlişki}

Araştırmada ele aldığımız bağımlı değişken örgütsel bağlılık ile bağımsız değişken lider-üye etkileşimi arasındaki ilişkiyi ele almadan önce, iki değişken arasında yapılmış geçmiş çalışmalara göz attığımızda ise; Eisenberger vd. (2010)'nin Amerika Birleşik Devletleri'nde bulunan bir sosyal hizmet kuruluşunda istihdam edilen 265 kişi üzerinde yaptı̆̆ çalışma sonucunda örgütsel bağlılık ile lider-üye etkileşimi arasında pozitif bir ilişki olduğu sonucuna ulaşılmıştır. Yine, Göksel ve Aydıntan (2012)'ın Gazi Üniversitesi Hastanesi'nde 
çalışan 57 baş, süpervizör/sorumlu hemşire üzerinde yapmış olduğu araştırmada örgütsel bağlilık ile liderüye etkileşimi arasında anlamlı bir ilişki olduğu sonucuna ulaşılmıştır. Alev ve Taş (2020) tarafından Gaziantep'in Şahinbey ilçesinde yer alan ilkokul ve ortaokullarda görev yapan 384 öğretmen üzerinde yapılan çalışmada lider-üye etkileşiminin örgütsel bağlllık ile pozitif yönde ve orta düzeyde bir ilişkiye sahip olduğu, benzer şekilde Kee vd. (2004)'nin 224 alt ve orta düzey yönetici üzerinde yapmış olduğu araştırmada ise örgütsel bağlllığın lider-üye etkileşiminde olumlu bir etkiye sahip olduğu görülmüştür.

\section{ARAŞTIRMANIN YÖNTEMI}

Çalışma, Ankara'da bölge müdürlüğü bulunan sigorta şirketleri çalışanlarının örgütsel bağlllığın örgütsel vatandaşlık davranışına ve lider-üye etkileşimine etkisini araştırmak amacıyla yapılmıştır. Veriler Türkiye'de faaliyet gösteren sigorta şirketlerinin, Ankara'da bulunan bölge müdürlüklerindeki çalışanlarından ilişkisel tarama yöntemiyle 02.10.2019 ile 19.12.2019 tarihleri arasında toplanmış olup; ulaşılabilir toplam evren sayısı 207 olarak saptanmış, evren için varsayılan standart sapma değerinin $\% 5$ olması sonucu araştırmanın örneklem büyüklüğü, \%99 güven düzeyinde, \%1'lik bir hata payı dikkate alınarak hesaplanmış ve $\left(n_{0}=665,64\right.$ olmak üzere $n=n_{0} / 1+n_{0} / \mathrm{N}$ ) 157 olarak tespit edilmiştir (Şahin ve Gürbüz, 2018: 129-130). Ankara'daki sigorta şirketlerinin bölge müdürlüklerinde istihdam edilen toplamda 204 çalışana anket ulaştırılmış, ancak 158 katılımcıdan geri dönüş alınabilmiştir. Ankete geri dönüş sağlanması sırasında, eksik verinin oluşmaması için anketin buna uygun tasarlanmış olması ve ankete geri dönüş sağlayanların sayısı örneklem büyüklügüne göre yeterli sayıya ulaşması sonucunda elde edilen veriler doğrultusunda analizler gerçekleştirilmiştir.

\subsection{Araştırmanın Modeli, Veri Toplama Araçlan ve Hipotezleri}

Ankara'da bölge müdürlügü bulunan sigorta şirketleri çalışanlarının örgütsel bağlılığının örgütsel vatandaşlık davranışına ve lider-üye etkileşimine etkisini araştırmak amacıyla oluşturulan araştırma modeli Şekil 1'de gösterilmiştir.

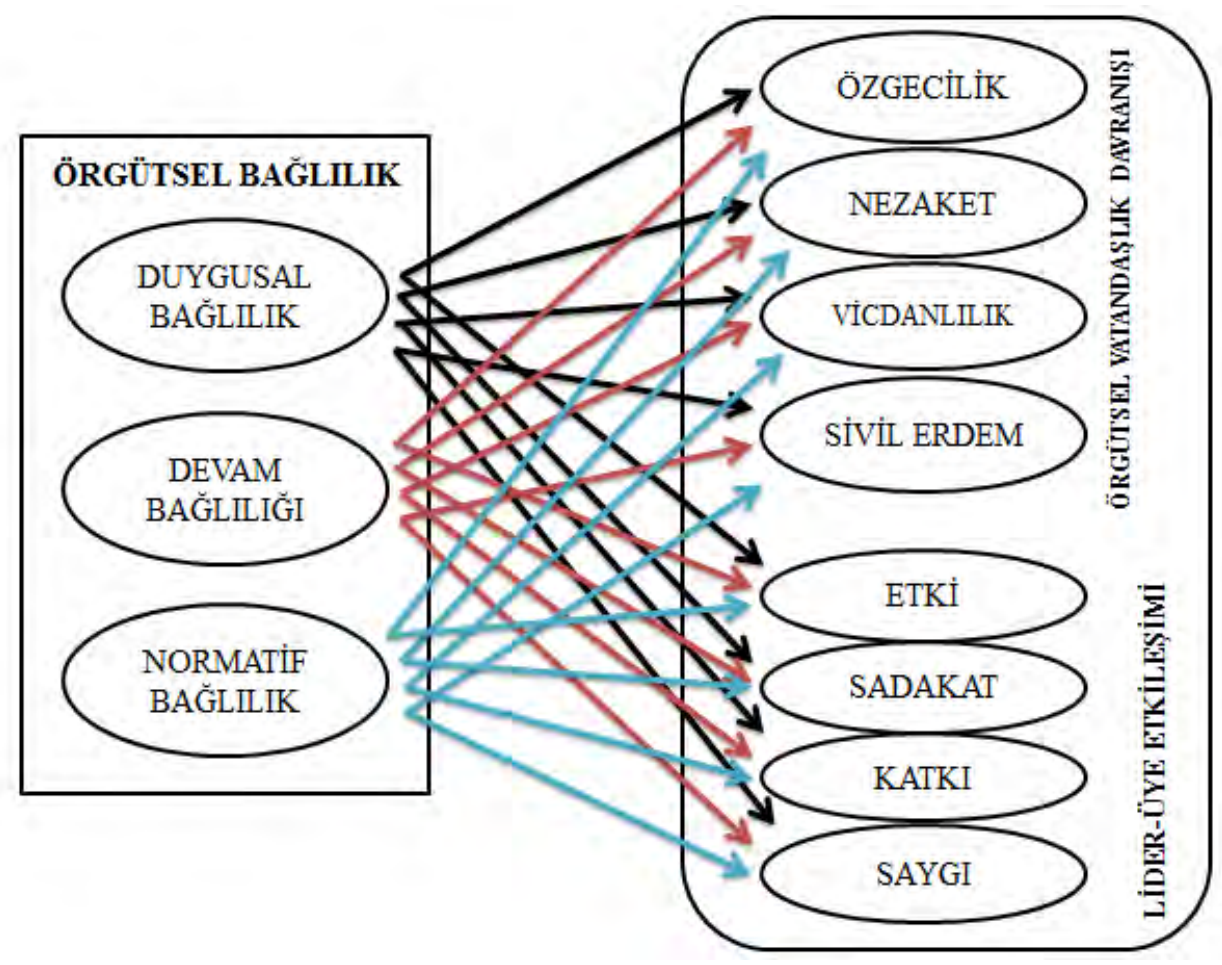

Şekil 1. Araştırmanın Modeli

Araştırmada örgütsel bağlllık, Meyer ve Allen (1984-1997) tarafından geliştirilmiş ve duygusal bağlllık, devam bağlılığı ve normatif bağllık olmak üzere üç boyuta ayrılmış olan "Örgütsel Bağl1lık Ölçeği" ile ölçülmüştür. Araştırmada kullanılan örgütsel bağlılık ölçeğinin Türkçe'ye derlemesi daha önce Bolat ve Bolat (2018) tarafından yapılmıştır. Araştırmada örgütsel vatandaşlık davranışı, Podsakoff vd. (1990) tarafından geliştirilen, 16 soru ve 4 boyuttan oluşan "Örgütsel Vatandaşlık Ölçeği” ile ölçülmüştür. Araştırmada kullanılan örgütsel vatandaşlık davranışı ölçeğinin Türkçe'ye derlemesi daha önce Dilek (2005) tarafından yapılmıştır. Araştırmada kullanılan diğer bir değişken olan lider üye etkileşimi ise Liden ve Maslyn (1998) 
tarafından geliştirilen, 12 madde ve 4 boyutta oluşan “Lider Üye Etkileşimi” ölçeğidir. Araştırmada kullanılan lider üye etkileşimi ölçeğinin Türkçe'ye derlemesi daha önce Çankır ve Palalar Alkan (2018) tarafından yapılmıştır. Çalışmada kullanılan anketlerde Likert ölçeğine sahip; 1. Kesinlikle Katılmıyorum, 2. Katılmıyorum, 3. Kararsızım, 4. Katılıyorum, 5. Kesinlikle Katılıyorum şeklinde 5 ifade bulunmakta olup bunun yanısıra kişilerin demografik verileri ile ilgili yaş, cinsiyet, eğitim, medeni durumları ve işletmede çalıştıkları pozisyonları gibi sorulara yer verilmiştir. Araştırma kapsamında kurulan hipotezler ise şu şekildedir;

H1a: Örgütsel bağlılığın alt boyutu olan duygusal bağlılık ile örgütsel vatandaşlık davranışının alt boyutu olan özgecilik arasında pozitif bir ilişki vardır.

H1b: Örgütsel bağlılığın alt boyutu olan duygusal bağl1lık ile örgütsel vatandaşlık davranışının alt boyutu olan nezaket arasında pozitif bir ilişki vardır.

H1،: Örgütsel bağlılığın alt boyutu olan duygusal bağlılık ile örgütsel vatandaşlık davranışının alt boyutu olan vicdanlılık arasında pozitif bir ilişki vardır.

H1d: Örgütsel bağlılığın alt boyutu olan duygusal bağl1lık ile örgütsel vatandaşlık davranışının alt boyutu olan sivil erdem arasında pozitif bir ilişki vardır.

H1e: Örgütsel bağlılığın alt boyutu olan duygusal bağlılık ile lider üye etkileşiminin alt boyutu olan etki arasında pozitif bir ilişki vardır.

H1: Örgütsel bağlılı̆̆ın alt boyutu olan duygusal bağlllık ile lider üye etkileşiminin alt boyutu olan sadakat arasında pozitif bir ilişki vardır.

H1g: Örgütsel bağl1lı̆̆ın alt boyutu olan duygusal bağl1lık ile lider üye etkileşiminin alt boyutu olan katkı arasında pozitif bir ilişki vardır.

H1h: Örgütsel bağlılığın alt boyutu olan duygusal bağlılık ile lider üye etkileşiminin alt boyutu olan sayg1 arasında pozitif bir ilişki vardır.

H2a: Örgütsel bağlılı̆̆ın alt boyutu olan devam bağlılı̆̆ı ile örgütsel vatandaşlık davranışının alt boyutu olan özgecilik arasında pozitif bir ilişki vardır.

H2b: Örgütsel bağlllığın alt boyutu olan devam bağlılı̆̆ ile örgütsel vatandaşlık davranışının alt boyutu olan nezaket arasında pozitif bir ilişki vardır.

H2،: Örgütsel bağl1lığın alt boyutu olan devam bağlılı̆̆ı ile örgütsel vatandaşlık davranışının alt boyutu olan vicdanlılık arasında pozitif bir ilişki vardır.

H2d: Örgütsel bağlılığın alt boyutu olan devam bağlılı̆̆ ile örgütsel vatandaşlık davranışının alt boyutu olan sivil erdem arasında pozitif bir ilişki vardır.

H2e: Örgütsel bağlılığın alt boyutu olan devam bağllı̆̆g ile lider üye etkileşiminin alt boyutu olan etki arasında pozitif bir ilişki vardır.

H2f: Örgütsel bağlılığın alt boyutu olan devam bağlılı̆̆ ile lider üye etkileşiminin alt boyutu olan sadakat arasında pozitif bir ilişki vardır.

H2g: Örgütsel bağlılığın alt boyutu olan devam bağlllığı ile lider üye etkileşiminin alt boyutu olan katk1 arasında pozitif bir ilişki vardır.

H2h: Örgütsel bağlılığın alt boyutu olan devam bağlılığı ile lider üye etkileşiminin alt boyutu olan sayg1 arasında pozitif bir ilişki vardır.

H3a: Örgütsel bağlllığın alt boyutu olan normatif bağllılık ile örgütsel vatandaşlık davranışının alt boyutu olan özgecilik arasında pozitif bir ilişki vardır.

H3b: Örgütsel bağllı̆̆ğı alt boyutu olan normatif bağllık ile örgütsel vatandaşlık davranışının alt boyutu olan nezaket arasında pozitif bir ilişki vardır.

H3،: Örgütsel bağlılığın alt boyutu olan normatif bağlılık ile örgütsel vatandaşlık davranışının alt boyutu olan vicdanlılık arasında pozitif bir ilişki vardır. 
H3d: Örgütsel bağlılığın alt boyutu olan normatif bağlılık ile örgütsel vatandaşlık davranışının alt boyutu olan sivil erdem arasında pozitif bir ilişki vardır.

H3e: Örgütsel bağlılı̆̆ın alt boyutu olan normatif bağlllık ile lider üye etkileşiminin alt boyutu olan etki arasında pozitif bir ilişki vardır.

H3f: Örgütsel bağlılığın alt boyutu olan normatif bağlılık ile lider üye etkileşiminin alt boyutu olan sadakat arasında pozitif bir ilişki vardır.

H3g: Örgütsel bağl1lı̆̆n alt boyutu olan normatif bağlılık ile lider üye etkileşiminin alt boyutu olan katkı arasında pozitif bir ilişki vardır.

H3h: Örgütsel bağlllı̆̆ın alt boyutu olan normatif bağlılık ile lider üye etkileşiminin alt boyutu olan sayg1 arasında pozitif bir ilişki vardır.

\subsection{Araştırmanın Bulguları}

\subsubsection{Demografik Veriler}

Araştırma kapsamında Ankara ilinde bölge müdürlüğü bulunan sigorta şirketlerinde çalışan 158 kişiden elde ettiğimiz veriler ışı̆̆ında; katılımcıların \%77,8'i kadın, \%22,2'si erkek, \%27,2'i evli ve \%72,8'u bekârdır. Kadın katılımcıların \%16,5'i evli, \%61,4'ü bekâr ve erkek katılımcıların ise \%10,8'i evli ve \%11,4'ü bekâr sonucuna ulaşılmıştır.

Araştırmaya katılan bireylerin çoğunluğunun \%76,6 ile lisans mezunlarından oluştuğu, yüksek lisans (\%11,4) ve önlisans $(\% 11,4)$ mezunlarının eşit olduğu, bunu ise lise $(\% 0,6)$ mezunlarının takip ettiği, bunun yanısıra ilkokul ve doktora mezunu çalışanın olmadığı görülmektedir. Araştırmaya katılanların çalışma süreleri incelendiğinde, çalışanların \%81'i gibi büyük bir çoğunluğunun 1-9 y1l arası kıdeme sahip olduğu görülmektedir.

\subsubsection{Korelasyon, Güvenilirlik ve Normal Dağılım Analizi}

Araştırma kapsamında kullanılan ölçeklerin güvenirliği hem korelasyon hem de regresyon analizleri açısından önem taşımaktadır. Bu nedenle yapılan analiz sonucu Tablo 1'de elde edilen Cronbach Alpha sayıları incelendiğinde, tüm değişkenlerin 0,7'nin üzerinde bir değere sahip olmakla güvenilir olduğu tespit edilmiştir. Çalışma kapsamında incelenen değişkenler arasındaki ilişkilerin derecesinin ve yönünün belirlenebilmesi amacıyla çoklu korelasyon analizi yapılmıştır. Analiz neticesinde elde edilen sonuçlar Tablo 1 'de yer almaktadır.

Tablo 1 incelendiğinde, ilk bağımsız değişken olan örgütsel bağllı̆ı̆ın alt boyutu duygusal bağlllık ile bağımlı değişkenlerden ilki olan örgütsel vatandaşlık davranışının alt boyutları özgecilik, nezaket, vicdanlılık ve sivil erdem arasında pozitif yönlü, orta düzeyde ve istatistiksel olarak anlamlı bir ilişki olduğu görülmüştür. Diğer bağımlı değişken olan lider üye etkileşiminin alt boyutları etki, sadakat, katkı ve saygı arasında da pozitif yönlü, orta düzeyde ve istatistiksel olarak anlamlı bir ilişki olduğu görülmektedir. İkinci bağımsız değişken olan örgütsel bağlılığın alt boyutu devam bağlılı̆̆ı ile bağımlı değişkenlerden ilki olan örgütsel vatandaşlık davranışının alt boyutları özgecilik, nezaket, vicdanlılık ve sivil erdem arasında pozitif yönlü, orta düzeyde ve istatistiksel olarak anlamlı bir ilişki olduğu görülmüştür. Diğer bağımlı değişken olan lider üye etkileşiminin alt boyutları etki, sadakat, katkı ve saygı arasında da pozitif yönlü, orta düzeyde ve istatistiksel olarak anlamlı bir ilişki olduğu görülmektedir. Diğer bir bağımsız değişken olan örgütsel bağlılığın alt boyutu normatif bağlılık ile bağımlı değişkenlerden ilki olan örgütsel vatandaşlık davranışının alt boyutları özgecilik, nezaket, vicdanlılık ve sivil erdem arasında pozitif yönlü, zayıf düzeyde ve istatistiksel olarak anlamlı bir ilişki olduğu tespit edilmiştir. İkinci bağımlı değişken olan lider üye etkileşiminin alt boyutları etki ile anlamlı bir ilişki bulunmaz iken; sadakat, katkı ve saygı arasında da pozitif yönlü, zayıf düzeyde ve istatistiksel olarak anlamlı bir ilişki olduğu görülmektedir. Ancak değişkenler arasında ilişkinin olması veya olmaması onların nedenselliği hakkında bilgiyi tam olarak veremediğinden regresyon analizi yapılmıştır. Değişkenler arasındaki nedensellik ilişkilerini incelemek amacıyla regresyon analizi yapılmadan önce dağılımın, normal olup olmadığına bakmak için çarpıklık ve basıklık değerleri test edilmiştir. Yapılan analizler sonucunda verilerin $\pm 1,5$ aralığı içerisinde olması nedeniyle parametrik analizler için yeterli normalliğe sahip olduğu görülmüştür (Hair, Black, Babin ve Anderson, 2014: 89-150), (Fidell ve Tabachnick,2015:117-143). 
Tablo 1. Çoklu Korelasyon, Güvenirlik ve Normal Dağılım Analiz Sonuçları

\begin{tabular}{|c|c|c|c|c|c|c|c|c|c|c|c|c|c|c|c|}
\hline Değișkenler & Ort. & SS & $a$ & $\begin{array}{l}\text { Skew. } \\
\text { Kurt. }\end{array}$ & 1 & 2 & 3 & 4 & 5 & 6 & 7 & 8 & 9 & 10 & 11 \\
\hline $\begin{array}{l}\text { Duygusal } \\
\text { Bağhllik }\end{array}$ & 3,98 &, 532 &, 749 & $\begin{array}{r}-, 175 \\
, 377 \\
\end{array}$ & 1 & & & & & & & & & & \\
\hline $\begin{array}{l}\text { Devam } \\
\text { Bağhligğ1 }\end{array}$ & 3,76 &, 626 &, 794 & $\begin{array}{r}-, 859 \\
, 406 \\
\end{array}$ &, $708^{* *}$ & 1 & & & & & & & & & \\
\hline $\begin{array}{l}\text { Normatif } \\
\text { Bağhllk }\end{array}$ & 3,18 & 680 &, 710 & $\begin{array}{r}-, 982 \\
, 629 \\
\end{array}$ &, $273^{* *}$ &, $520^{* *}$ & 1 & & & & & & & & \\
\hline $\begin{array}{ll}\text { ÖVD } & \text { Alt } \\
\text { Boyutu } & \\
\text { Özgecilik } & \\
\end{array}$ & 4,26 &, 568 &, 827 & $\begin{array}{r}-, 495 \\
, 808\end{array}$ &, $327^{* *}$ &, $330^{*}$ &, $154^{*}$ & 1 & & & & & & & \\
\hline $\begin{array}{ll}\text { OVD } & \text { Alt } \\
\text { Boyutu } & \\
\text { Nezaket } & \\
\end{array}$ & 4,27 &, 561 &, 826 & $\begin{array}{l}-, 352 \\
, 531\end{array}$ &, $367^{* *}$ & $281^{* *}$ &, $195^{* *}$ & $680^{7 *}$ & 1 & & & & & & \\
\hline $\begin{array}{ll}\text { ÖVD } & \text { Alt } \\
\text { Boyutu } & \\
\text { Vicdanlllik } & \\
\end{array}$ & 4,12 &, 552 &, 772 & $\begin{array}{r}-, 381 \\
, 881\end{array}$ &, $362^{* *}$ &, $329^{n *}$ &, $292^{* *}$ &, $557^{* *}$ &, $614^{* *}$ & 1 & & & & & \\
\hline $\begin{array}{lr}\text { OVD } & \text { Alt } \\
\text { Boyutu } & \text { Sivil } \\
\text { Erdem } & \\
\end{array}$ & 4,12 &, 695 & 916 & $\begin{array}{l}-, 592 \\
, 495\end{array}$ &, $462^{* *}$ &, $410^{n *}$ & $245^{m *}$ &, $628^{* *}$ &, $592^{* *}$ &, $589^{* *}$ & 1 & & & & \\
\hline $\begin{array}{l}\text { Lider-üye } \\
\text { Etkileşimi Alt } \\
\text { boyutu Etki }\end{array}$ & 3,94 &, 774 & 901 & $\begin{array}{r}-, 523 \\
, 506\end{array}$ &, $536^{n *}$ &, $475^{n *}$ &, 094 &, $391^{* \pi}$ &, $370^{n \pi}$ &, $332^{* \pi}$ &, $345^{* *}$ & 1 & & & \\
\hline $\begin{array}{l}\text { Lider-üye } \\
\text { Etkileşimi Alt } \\
\text { boyrutu Sadakat }\end{array}$ & 3,78 &, 758 &, 821 & $\begin{array}{l}-, 672 \\
, 630\end{array}$ &, $503^{* *}$ &, $559^{* *}$ &, $298^{* *}$ &, $323^{* *}$ &, $314^{* *}$ &, $374^{* *}$ &, $355^{* *}$ &, $663^{* *}$ & 1 & & \\
\hline $\begin{array}{l}\text { Lider-üye } \\
\text { Etkileșimi Alt } \\
\text { boyutu Katka }\end{array}$ & 3,99 &, 635 &, 819 & $\begin{array}{r}-, 420 \\
, 972\end{array}$ &, $522^{* *}$ &, $532^{* *}$ &, $228^{* \pi}$ & ,439* & ,439* &, $477^{* *}$ &, $503^{* *}$ &, $650^{* *}$ &, $724^{* *}$ & 1 & \\
\hline $\begin{array}{l}\text { Lider-üye } \\
\text { Etkileşimi Alt } \\
\text { boyrutu Saygl }\end{array}$ & 3,95 &, 716 &, 877 & $\begin{array}{l}-, 958 \\
1,315\end{array}$ &, $546^{* *}$ &, $555^{m *}$ &, $263^{* *}$ &, $461^{* \pi}$ &, $395^{* *}$ &, $516^{* *}$ &, $480^{* *}$ &, $592^{* *}$ &, $640^{* *}$ &, $739^{* *}$ & 1 \\
\hline
\end{tabular}

${ }^{* *}$ Korelasyonlar \%99 güven aralığı içinde istatistiksel olarak anlamlıdır (2-tailed).

${ }^{*}$ Korelasyonlar \%95 güven aralığ

\subsubsection{Faktör ve Regresyon Analizi}

Araştırma kapsamında kullanılan ölçeklerin yapısal geçerliliği test etmek amacıyla yapılan keşfedici faktör analizi (KFA) sonucunda, Kaiser-Meyer-Olkin (KMO) örneklem yeterlilik değerinin 0,865 olduğu ve örneklem büyüklüğünün faktör analizi için çok iyi seviyede olduğu görülmüştür (Field, 2009: 627). Ayrica Bartlett küresellik testinin anlamlı olması $\left[x^{2}(1035)=4952,992 p<, 001\right]$ maddeler arasındaki korelasyon ilişkilerinin faktör analizi için uygun olduğunu göstermektedir (Şahin ve Gürbüz, 2018: 317). Bununla birlikte faktör analizi kapsamında; "Her zaman dakik olmaya çalışırım.", "Hiçbir zaman uzun öğle araları almak istemem.", "Liderim, işle ilgili olarak açıkça bir hata yapsam bile beni başkalarına karşı savunur.", "Liderim, benim görev tanımımın dışında olan işlere de destek verir ve gerekli kaynakları sağlar.", "Bu kuruluşun sorunlarını gerçekten kendi sorunlarım gibi hissediyorum.", "Benim için avantajlı da olsa kuruluşumdan şu anda ayrılmanın doğru olmadığını hissediyorum.", "Kuruluşumdan şimdi ayrılsam kendimi suçlu hissederim.", "Kuruluşuma çok şey borçluyum.", "Şu anda kuruluşumdan ayrılmak istediğime karar versem, hayatımın çoğu alt üst olur." maddelerinin faktör yükleri beklenilen değerin altında olduğu için analize dahil edilmemiştir.

Ankara ilinde bölge müdürlügü bulunan sigorta şirketleri çalışanları üzerine yapılan araştırma sonucunda ilk bağımsız değişken olan örgütsel bağllı̆̆ın alt boyutu duygusal bağlılı̆̆ın ile bağımlı değişkenlerden ilki örgütsel vatandaşlık davranışının alt boyutları özgecilik, nezaket, vicdanlılık ve sivil erdem ile diğer bağımlı değişken olan lider üye etkileşiminin alt boyutları etki, sadakat, katkı ve saygıyı ne oranda açıkladığını anlamak amacıyla regresyon analizi yapılmıştır. Değişkenler arasındaki ilişkileri anlayabilmek için yapılan regresyon analizine dair sonuçlar Tablo 2 'de gösterilmiştir. Buna göre $\mathrm{R}^{2}$ değerleri bağımlı değerdeki değişimin ne kadarının bağımsız değişkenler tarafından açıklandığını göstermektedir (Şahin ve Gürbüz, 2018: 268). Görüldüğü üzere, bağımlı ve bağımsız değişkenlerin ayrı ayrı test edildiği regresyon sonuçları istatistiksel olarak anlamlıdır ( $\mathrm{p}<, 05)$. Değerler incelendiğinde, ilk bağımlı değişken olan örgütsel vatandaşlık davranışının alt boyutu özgeciliğin \%32'sinin, nezaketin ve vicdanlılığın \%36'sının ve sivil erdemdeki değişimin \%46'sının; ikinci bağımlı değişken olan lider üye etkileşiminin alt boyutu etkinin \%53'ünün, sadakatin \%50'sinin, katkının \%52'sinin ve saygının \%54'ünün bağımsız değişken olan örgütsel bağlılı̆̆ın alt boyutu duygusal bağlılık tarafından açıklandığı görülmektedir. 
Tablo 2. Örgütsel Bağlılık Alt Boyutu olan Duygusal Bağlılık ile Bağımlı Değişkenlerin Alt Boyutlarına ait Regresyon Analiz Sonuçları

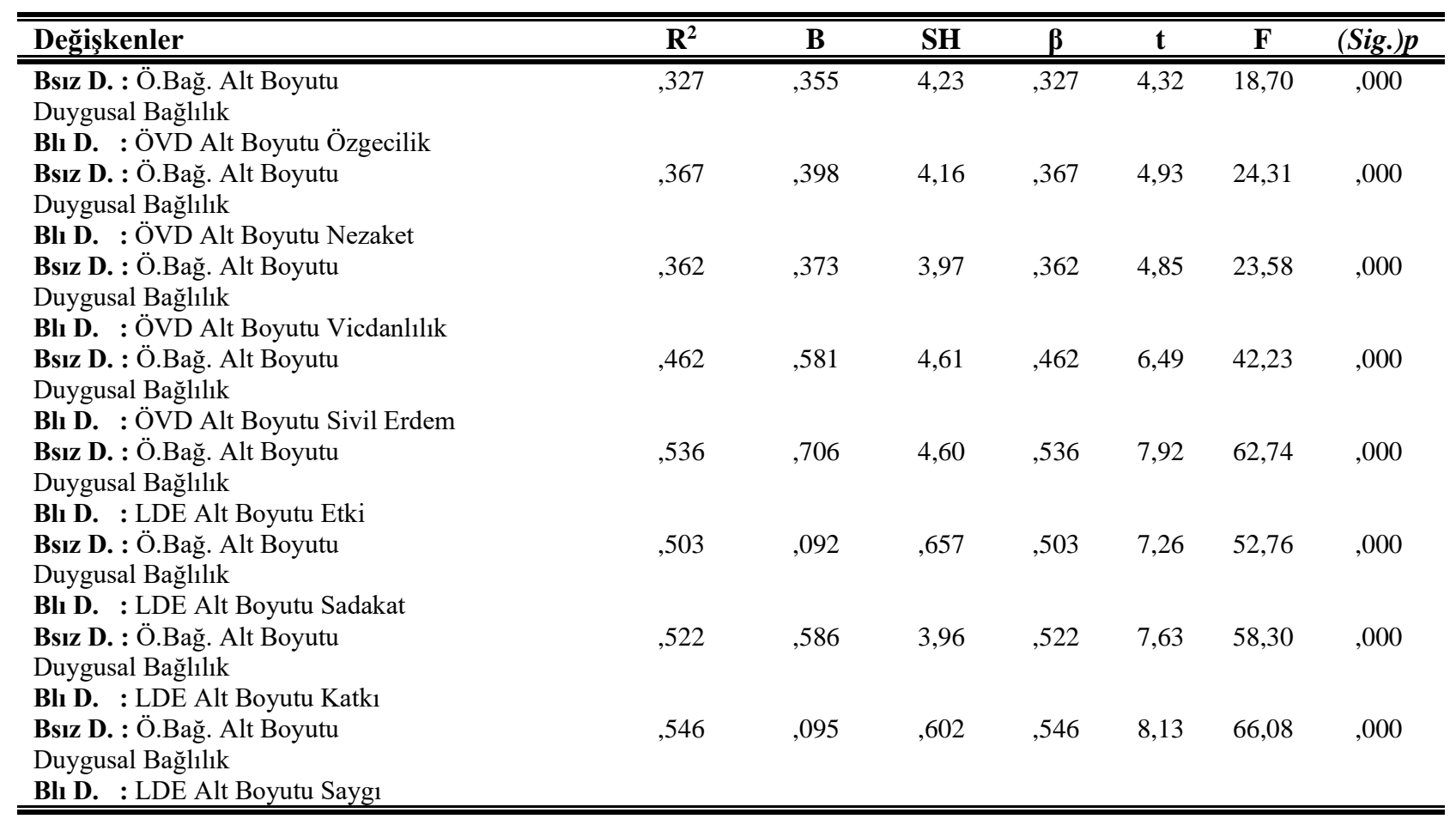

Analizler doğrultusunda hipotez sonuçları şu şekildedir;

H1: Örgütsel bağlılı̆̆ın alt boyutu olan duygusal bağlılık ile örgütsel vatandaşlık davranışının alt boyutu olan özgecilik arasında pozitif bir ilişki vardır. (Kabul)

H1b: Örgütsel bağlılığın alt boyutu olan duygusal bağlılık ile örgütsel vatandaşlık davranışının alt boyutu olan nezaket arasında pozitif bir ilişki vardır. (Kabul)

H1: Örgütsel bağlılığın alt boyutu olan duygusal bağlılık ile örgütsel vatandaşlık davranışının alt boyutu olan vicdanlılık arasında pozitif bir ilişki vardır. (Kabul)

H1d: Örgütsel bağlılığın alt boyutu olan duygusal bağl1lık ile örgütsel vatandaşlık davranışının alt boyutu olan sivil erdem arasında pozitif bir ilişki vardır. (Kabul)

H1e: Örgütsel bağll1ı̆̆n alt boyutu olan duygusal bağlılık ile lider üye etkileşiminin alt boyutu olan etki arasında pozitif bir ilişki vardır. (Kabul)

H1: Örgütsel bağlılığın alt boyutu olan duygusal bağl1lık ile lider üye etkileşiminin alt boyutu olan sadakat arasında pozitif bir ilişki vardır. (Kabul)

H1g: Örgütsel bağl1lı̆̆ın alt boyutu olan duygusal bağl1lık ile lider üye etkileşiminin alt boyutu olan katkı arasında pozitif bir ilişki vardır. (Kabul)

H1h: Örgütsel bağlllığın alt boyutu olan duygusal bağlılık ile lider üye etkileşiminin alt boyutu olan sayg1 arasında pozitif bir ilişki vardır. (Kabul)

İkinci bağımsız değişken olan örgütsel bağlılığın alt boyutu devam bağl1lığı ile bağımlı değişkenlerden ilki olan örgütsel vatandaşlık davranışının alt boyutları özgecilik, nezaket, vicdanlılık ve sivil erdem ile diğer bağımlı değişken olan lider üye etkileşiminin alt boyutları etki, sadakat, katkı ve saygıyı ne oranda açıkladığını anlamak amacıyla regresyon analizi yapılmıştır. Değişkenler arasındaki ilişkileri anlayabilmek için yapılan regresyon analizine dair sonuçlar Tablo 3'de gösterilmiştir. Buna göre $\mathrm{R}^{2}$ değerleri bağımlı değerdeki değişimin ne kadarının bağımsız değişkenler tarafından açıklandığını göstermektedir (Şahin ve Gürbüz, 2018: 268). Görüldüğü üzere, bağımlı ve bağımsız değişkenlerin ayrı ayrı test edildiği regresyon sonuçları istatistiksel olarak anlamlıdır ( $\mathrm{p}<, 05)$. Değerler incelendiğinde, ilk bağımlı değişken olan örgütsel vatandaşlık davranışının alt boyutu özgeciliğin \%33'ünün, nezaketin \%28'inin, vicdanlılı̆̆ın \%32'sinin ve sivil erdemdeki 
değişimin \%41'inin; ikinci bağımlı değişken olan lider üye etkileşiminin alt boyutu etkinin \%47'sinin, sadakatin \%55'inin, katkının \%53'ünün ve saygının \%55'inin bağımsız değişken olan örgütsel bağlılığın alt boyutu devam bağlılığı tarafından açıklandığı görülmektedir.

Tablo 3. Örgütsel Bağlılık Alt Boyutu olan Devam Bağlılı̆̆ı ile Bağımlı Değişkenlerin Alt Boyutlarına ait Regresyon Analiz Sonuçları

\begin{tabular}{|c|c|c|c|c|c|c|c|}
\hline Değişkenler & $\mathbf{R}^{2}$ & B & SH & $\beta$ & $t$ & $\mathbf{F}$ & $\overline{(\text { Sig. }) p}$ \\
\hline $\begin{array}{l}\text { Bsız D. : Ö.Bağ. Alt Boyutu } \\
\text { Devam Bağglliğg }\end{array}$ & "330 & $2,2,35$ & "4,23 & ב, 330 & 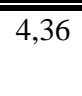 & 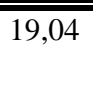 & "000 \\
\hline $\begin{array}{l}\text { Blı D. : ÖVD Alt Boyutu Özgecilik } \\
\text { Bsiz D. : Ö.Bağ. Alt Boyutu } \\
\text { Devam Bağgllı̆̆1 }\end{array}$ & 281 & 2,00 & 4,30 & 281 & 3,65 & 13,35 & ,000 \\
\hline $\begin{array}{l}\text { Blı D. : ÖVD Alt Boyutu Nezaket } \\
\text { Bszz D. : Ö.Bağ. Alt Boyutu } \\
\text { Devam Bağlllığ } 1\end{array}$ & 329 & ,537 & 4,02 & 329 & 4,34 & 18,87 & ,000 \\
\hline $\begin{array}{l}\text { Blı D. : ÖVD Alt Boyutu Vicdanlılık } \\
\text { Bsiz D. : Ö.Bağ. Alt Boyutu } \\
\text { Devam Bağlilığ } \\
\text { BuD }\end{array}$ & 410 & 3,39 & 4,74 & ,410 & 5,61 & 31,47 & , 000 \\
\hline $\begin{array}{l}\text { Blı D. : ÖVD Alt Boyutu Sivil Erdem } \\
\text { Bszz D. : Ö.Bağ. Alt Boyutu } \\
\text { Devam Bağl1lığ } 1\end{array}$ & 475 & 4,11 & 4,79 & ,475 & 6,74 & 45,47 & 000 \\
\hline $\begin{array}{l}\text { Blı D. : LDE Alt Boyutu Etki } \\
\text { Bstz D. : Ö.Bağ. Alt Boyutu } \\
\text { Devam Bağ } 111 \text { ğg } 1\end{array}$ & ,559 & 675 & 630 & 559 & 8,41 & 70,72 & ,000 \\
\hline $\begin{array}{l}\text { Blı D. : LDE Alt Boyutu Sadakat } \\
\text { Bsız D. : O..Bağ. Alt Boyutu } \\
\text { Devam Bağglilğg1 }\end{array}$ & 532 & 3,93 & 3,93 & ,532 & 7,84 & 61,58 & 000 \\
\hline $\begin{array}{l}\text { Blı D. : LDE Alt Boyutu Katkı } \\
\text { Bsız D. : Ö.Bağ. Alt Boyutu } \\
\text { Devam Bağllilğ } 1 \\
\text { Blı D. : LDE Alt Boyutu Saygı }\end{array}$ & ,555 & 635 & 597 & 555 & 8,33 & 69,52 & ,000 \\
\hline
\end{tabular}

Analizler doğrultusunda hipotez sonuçları şu şekildedir;

H2a: Örgütsel bağlılığın alt boyutu olan devam bağlılı̆̆ı ile örgütsel vatandaşlık davranışının alt boyutu olan özgecilik arasında pozitif bir ilişki vardır. (Kabul)

H2b: Örgütsel bağlılığın alt boyutu olan devam bağlılı̆̆ı ile örgütsel vatandaşlık davranışının alt boyutu olan nezaket arasında pozitif bir ilişki vardır. (Kabul)

H2: Örgütsel bağlılığın alt boyutu olan devam bağlılığı ile örgütsel vatandaşlık davranışının alt boyutu olan vicdanlılık arasında pozitif bir ilişki vardır. (Kabul)

H2d: Örgütsel bağlılığın alt boyutu olan devam bağlılı̆̆ ile örgütsel vatandaşlık davranışının alt boyutu olan sivil erdem arasında pozitif bir ilişki vardır. (Kabul)

H2: Örgütsel bağlılığın alt boyutu olan devam bağlılı̆̆ ile lider üye etkileşiminin alt boyutu olan etki arasında pozitif bir ilişki vardır. (Kabul)

H2f: Örgütsel bağlllığın alt boyutu olan devam bağlılığı ile lider üye etkileşiminin alt boyutu olan sadakat arasında pozitif bir ilişki vardır. (Kabul)

H2g: Örgütsel bağlılığın alt boyutu olan devam bağlılığı ile lider üye etkileşiminin alt boyutu olan katkı arasında pozitif bir ilişki vardır. (Kabul)

H2h: Örgütsel bağlılığın alt boyutu olan devam bağlılığı ile lider üye etkileşiminin alt boyutu olan sayg1 arasında pozitif bir ilişki vardır. (Kabul)

Üçüncü ve son bağımsız değişken olan örgütsel bağlılığın alt boyutu normatif bağlılık ile bağımlı değişkenlerden ilki olan örgütsel vatandaşlık davranışının alt boyutları özgecilik, nezaket, vicdanlılık ve sivil erdem ile diğer bağımlı değişken olan lider üye etkileşiminin alt boyutları etki, sadakat, katkı ve saygıyı ne oranda açıkladığını anlamak amacıyla regresyon analizi yapılmıştır. Değişkenler arasındaki ilişkileri anlayabilmek için yapılan regresyon analizine dair sonuçlar Tablo 4'de gösterilmiştir. Buna göre $\mathrm{R}^{2}$ değerleri bağımlı değerdeki değişimin ne kadarının bağımsız değişkenler tarafından açıklandığını göstermektedir 
(Şahin ve Gürbüz, 2018: 268). Görüldüğü üzere, bağımlı ve bağımsız değişkenlerin ayrı ayrı test edildiği regresyon sonuçları ÖVD'nin alt boyutu olan özgecilik ve LMX'in alt boyutu olan etki haricinde istatistiksel olarak anlamlıdır $(\mathrm{p}<, 05)$. Değerler incelendiğinde, ilk bağımlı değişken olan örgütsel vatandaşlık davranışının alt boyutu nezaketin \%19'unun, vicdanlılığın \%29'unun ve sivil erdemdeki değişimin \%24'ünün; ikinci bağımlı değişken olan lider üye etkileşiminin alt boyutu sadakatin \%29'unun, katkının \%22'sinin ve saygının \%26'sının bağımsız değişken olan örgütsel bağlılığın alt boyutu normatif bağlılık tarafından açılandığı görülmektedir. Ancak bağımsız değişken olan örgütsel bağlılığın alt boyutu normatif bağlılık ile ÖVD'nin alt boyutu olan özgecilik $(p=, 054)$ ve LMX'in alt boyutu olan etki $(p=, 242)$ arasinda anlamlı bir ilişkinin olmadığı tespit edilmiştir.

Tablo 4. Örgütsel Bağlılık Alt Boyutu olan Normatif Bağlılık ile Bağımlı Değişkenlerin Alt Boyutlarına ait Regresyon Analiz Sonuçları

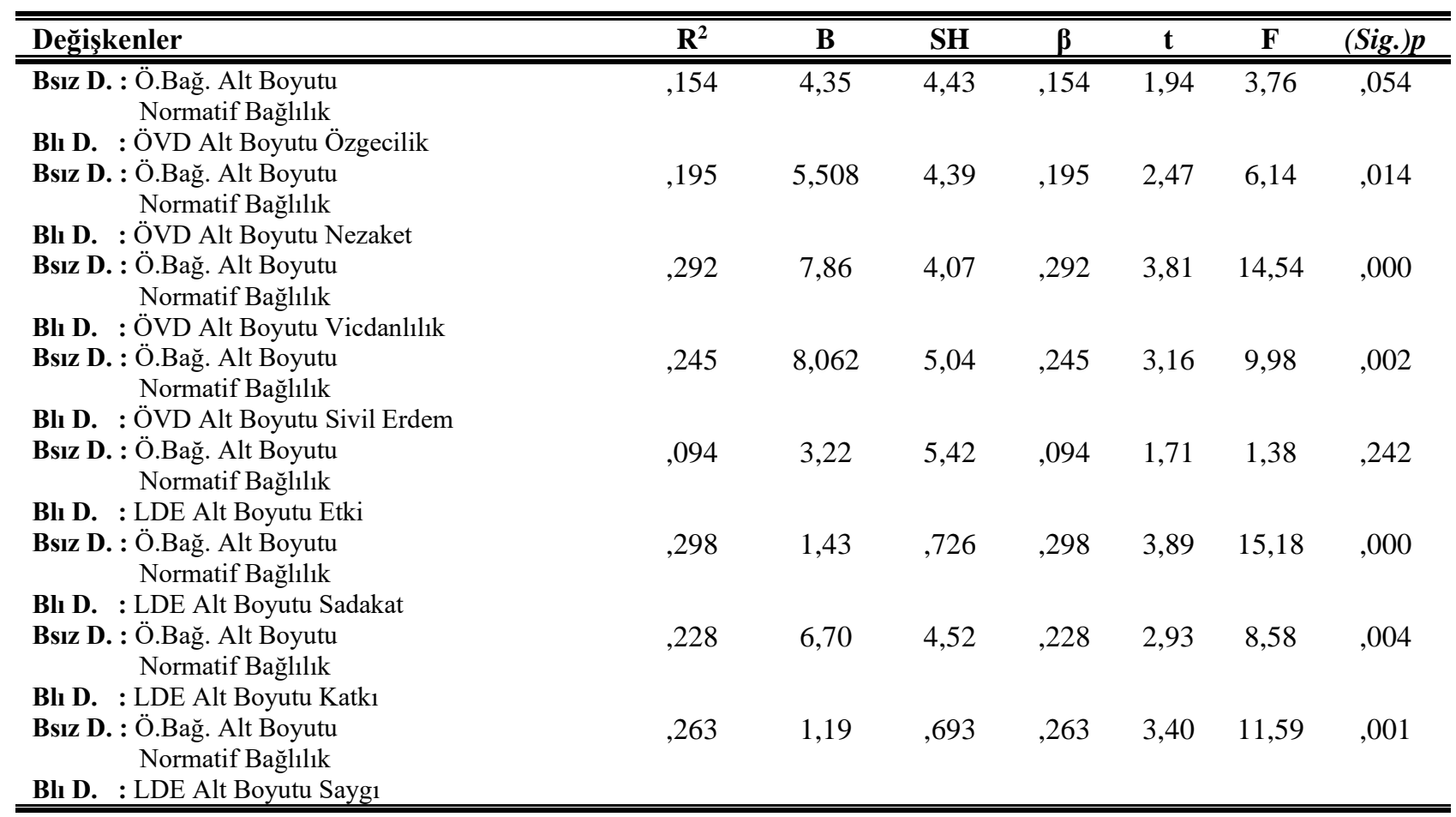

Analizler doğrultusunda hipotez sonuçları şu şekildedir;

H3a: Örgütsel bağlılığın alt boyutu olan normatif bağlılık ile örgütsel vatandaşlık davranışının alt boyutu olan özgecilik arasında pozitif bir ilişki vardır. (Red)

H3b: Örgütsel bağlılı̆̆ın alt boyutu olan normatif bağll1ık ile örgütsel vatandaşlık davranışının alt boyutu olan nezaket arasında pozitif bir ilişki vardır. (Kabul)

H3c: Örgütsel bağll1ığın alt boyutu olan normatif bağlılık ile örgütsel vatandaşlık davranışının alt boyutu olan vicdanlılık arasında pozitif bir ilişki vardır. (Kabul)

H3d: Örgütsel bağlılığın alt boyutu olan normatif bağlılık ile örgütsel vatandaşlık davranışının alt boyutu olan sivil erdem arasında pozitif bir ilişki vardır. (Kabul)

H3e: Örgütsel bağlllı̆̆ın alt boyutu olan normatif bağlllık ile lider üye etkileşiminin alt boyutu olan etki arasında pozitif bir ilişki vardır. (Red)

H3f: Örgütsel bağlılığın alt boyutu olan normatif bağlllık ile lider üye etkileşiminin alt boyutu olan sadakat arasında pozitif bir ilişki vardır. (Kabul)

H3: Örgütsel bağlılı̆̆ın alt boyutu olan normatif bağlılık ile lider üye etkileşiminin alt boyutu olan katk1 arasında pozitif bir ilişki vardır. (Kabul)

H3h: Örgütsel bağlllığın alt boyutu olan normatif bağlılık ile lider üye etkileşiminin alt boyutu olan sayg1 arasında pozitif bir ilişki vardır. (Kabul) 


\section{SONUÇ VE TARTIŞMA}

Araştırma çerçevesinde son zamanlarda hem örgütsel düzeyde çalışma yapan bilim adamlarının hem de işverenlerin işe alım süreçlerinde ve mevcut çalışanların bireysel performanslarının arttırılması amacıyla üzerinde durdukları örgütsel bağlılık, örgütsel vatandaşlık davranışı ve lider-üye etkileşimi kavramları ve bunların alt boyutları ile ilgili kapsamlı bir çalışma gerçekleştirilmiştir. Genel olarak; örgütsel bağlılık organizasyonunun kuruluş ve amaçlarını benimsemiş ve resmi gerekliliklerinden fazla çaba gösteren çalışanları, örgütsel vatandaşlık davranışı, temel iş gereksinimlerinin üzerinde örgüte yönelik sergilenen iş yeri davranışlarını ve lider üye etkileşimi ise, lider ile çalışan arasında iş gerekliliklerinin yerine getirilmesi sırasında oluşabilecek davranışsal boyutları içermektedir.

Çalışma Ankara ilinde bölge müdürlüğü bulunan sigorta şirketleri çalışanlarının örgütsel bağlılığının örgütsel vatandaşlık davranışına ve lider üye etkileşimine etkisini araştırmak amacıyla yapılmıştır. Araştırma bulgularından hareketle, örgütsel bağlllı̆̆ın alt boyutu olan duygusal bağlllık ile örgütsel vatandaşlık davranışının alt boyutları olan özgecilik, nezaket, vicdanlılık ve sivil erdem ile arasında pozitif bir ilişki olduğu ve aynı zamanda lider üye etkileşiminin alt boyutları olan etki, sadakat, katkı ve saygı ile de arasında pozitif bir ilişki olduğu görülmüştür. Örgütsel bağlllı̆̆ın diğer bir alt boyutu olan devam bağlılı̆̆g ile ÖVD'nin alt boyutları olan özgecilik, nezaket, vicdanlılık ve sivil erdem arasında pozitif bir ilişki olduğu ve yine lider üye etkileşiminin alt boyutları olan etki, sadakat, katkı ve saygı ile arasında pozitif bir ilişki olduğu saptanmıştır. Araştırmanın son kıstası, örgütsel bağlllığın alt boyutu olan normatif bağlılık ile ÖVD'nin alt boyutları olan nezaket, vicdanlılık ve sivil erdem arasında pozitif bir ilişki görülürken, özgecilik ile arasında anlamlı bir ilişkinin olmadığı ve lider üye etkileşiminin alt boyutları olan saygı, sadakat ve katkı ile arasında pozitif bir ilişki olduğu fakat etki ile arasında anlamlı bir ilişkinin olmadığı tespit edilmiştir. Araştırmanın sonuçlarından yola çıkarak örgütsel bağlılığın alt boyutları olan duygusal bağlılık ve devam bağlılı̆̆ ile ÖVD ve lider-üye etkileşiminin alt boyutları arasında pozitif bir ilişkinin olması daha önce farklı alanlarda bu konu ile ilgili yapılan çalışmalarla benzerlik göstermektedir. Ancak örgütsel bağl1lı̆̆ın diğer bir alt boyutu olan normatif bağlılık ile ÖVD'nin nezaket vicdanlılık ve sivil erdem alt boyutları ile pozitif, özgecilik ile anlamsız; lider-üye etkileşiminin saygı, sadakat, katkı ile pozitif, fakat etki ile anlamsız bir korelasyon içerisinde olması normatif bağlllığın bireylerin kişisel özelliklerinden çok, kültürel farklılıklarından ve örgüt kültürü anlayışından etkilendiğini bu nedenle de sigorta sektöründe çalışanların normatif bağlılık düzeylerinin, özgecilik (yardımseverlik) ve etki boyutlarına doğrudan etki etmediğini söylemek mümkün olacaktır. Aynı şekilde elde edilen sonuçlar, literatürde yer alan birçok çalışma ile desteklenmiş olsa da ilaveten çalışmanın bulguları; araştırmanın sadece Ankara ilinde faaliyet gösteren sigorta şirketleri üzerinde yürütülmesi nedeniyle, Türkiye veya dünya genelinde sigorta şirketlerinden elde edilecek daha fazla veri ile de genellenebilir.

Sonuç olarak; sigorta sektöründe iş verenlerin veya yöneticilerin gerek rekabet koşullarının hakim olduğu bir piyasada devamlılıklarını sürdürebilmeleri gerekse de çalışanlarının iş performanslarını arttırabilmeleri amacıyla istihdam edilen personellerin örgütsel bağlll1klarının sağlanması için stratejiler belirlemeleri kurum içi sadakatin oluşması için ödül ve ücret sistemleri geliştirmeleri tavsiye edilmektedir. Ayrıca tüm bu önerilerin yerine getirilmesi ile lider-üye etkileşiminin otonom olarak gelişeceği ve çalışanların kendilerini örgütün doğal bir parçası görerek ve vatandaşlık davranışları sergileyerek kurum çıkarlarını her şeyden üstün tutacaklarını söylemek mümkün olacaktır. Bu bakımdan çalışma, örgütsel bağllılı, örgütsel vatandaşlık davranışı ve lider-üye etkileşimi ile ilgili çalışma yapacak olan araştırmacılara yol gösterebilir, işverenlerin işe alım süreçlerinde ve mevcut çalışanlar üzerinde uygulayacağı stratejiler ile ilgili de öneriler sunabilir. Ayrıca araştırma ileriki çalışmalarda farklı sektörlere uygulanarak veya Türk sigorta sektöründe daha fazla kişiye ulaşılarak genişletilebilir. Ek olarak araştırma, bu konuda yapılacak çalışmalar için bir dayanak olmak ile birlikte araştırmacılara yeni fikirler ve değişkenler arası ilişkilerde farklı kombinasyonların denenmesi dolayısıyla yeni bulguların ortaya çıkmasına da fayda sağlayabilecek niteliktedir. 


\section{KAYNAKÇA}

Allen, N. J., Meyer, J. P. (1990). The Measurement and Antecedents Of Affective, Continuance and Normative Commitment to The Organization. Journal of Occupational Psychology, 63(1), 1-18.

Alev, S., Taş, D. (2020). Lider-Üye Etkileşimi, Tükenmişlik ve Örgütsel Bağlllık Arasındaki İlişki: Öğretmenler Üzerine Bir Araştırma. Anemon Muş Alparslan Üniversitesi Sosyal Bilimler Dergisi, 8(5), 1611-1620.

Barnard, C. (1938). The Functions of The Executive. Cambridge, MA: Harvard University Press.

Becker, H. S. (1960). Notes on the Concept of Commitment. American Journal of Sociology, 66(1).

Bogler, R., Somech, A. (2004). Influence of Teacher Empowerment on Teachers Organizational Citizenship Behaviour in Schools. Teaching and Teacher Education, 20, 277-289.

Bolat, O. İ., Bolat, T. (2008). Otel İşletmelerinde Örgütsel Bağlllık ve Örgütsel Vatandaşlık Davranışı İlişkisi. Balkesir Üniversitesi Sosyal Bilimler Enstitüsü Dergisi, 11(19), 75-94.

Çankır, B., Alkan, D. P. (2018). Lider-Üye Etkileşiminin Örgütsel Özdeşleşme Üzerindeki Etkisinde Dağıtım Adaletinin Aracılık Rolü. İşletme Araştırmaları Dergisi, 10(3),929-949.

Dienesch R. M., Liden, R. C. (1986). Leader-Member Exchange Model of Leadership: A Critique and Further Development. Academy of Management Review, 11(3).

Dilek, H. (2005). Liderlik Tarzlarının ve Adalet Algısının; Örgütsel Bağlllık, İş Tatmini ve Örgütsel Vatandaşlık Davranışı Üzerine Etkilerine Yönelik Bir Araştırma (Yayınlanmamış Doktora Tezi). Gebze Yüksek Teknoloji Üniversitesi, Gebze.

Dockery, T. M., Steiner, D. D. (1990). The Role of the Initial Interaction in Leader- Member Exchange. Group $\mathcal{E}$ Organization Management, 15(4), 397.

Eisenberger, R., Stinglhamber, F., Becker, T. E., Mueller, M. S., Karagonlar, G., Neves, P., Morales, G. G. (2010). Leader Member Exchange and Affective Organizational Commitment: The Contribution of Supervisor's Organizational Embodiment. Journal of Applied Psychology, 95(6), 1085-1103.

Fairhurst, G. T., Chandler, T. A. (1989). Social Structure in Leader-Member Interaction. Communication Monographs, 56(3), 215.

Fidell, L. S., Tabachnick, B. G. (2015). Çok Değişkenli İstatistiklerin Kullanımı (6. Baskı). Nobel Yayın ve Dağıtım.

Field, A. (2009). Discovering Statistics Using SPSS (3. Baskı). SAGE Publications.

Graen, G. B., Uhl-Bien, M. (1995). Relationship-Based Approach to Leadership: Development Of LeaderMember Exchange (LMX) Theory of Leadership over 25 Years: Applying A Multi-Level Multi-Domain Perspective. The Leadership Quarterly, 6(2), 219-247.

Göksel, A., Aydıntan, B. (2012). Lider-Üye Etkileşimi Düzeyinin Örgütsel Bağlılık Üzerine Etkisi: Görgül Bir Araştırma. Süleyman Demirel Üniversitesi İktisadi ve İdari Bilimler Fakültesi Dergisi, 17(2), 247-271.

Haga, W. J., Graen, G., Dansereau, F. (1975). A Vertical Dyad Linkage Approach to Leadership Within Formal Organizations: A Longitudinal Investigation of The Role Making Process. Organizational Behavior and Human Performance, 13(1), 46-78.

Hair, J. F., Black, W. C., Babin, B. C., Anderson, R. E. (2014). Multivariate Data Analysis: Pearson New International Edition (7. Baskl). Essex: Pearson Education Limited.

Ibrahım, M. A., Aslinda, A. (2013). Relationship Between Organizational Commitment and Organisational Citizenship Behavior (OCB) At Goverment-Owned Corporation Companies. Journal of Public Administration and Governance, 3(3), 35-42.

Jacobs, T. (1971). Leadership and Exchange in Formal Organizations. Alexandria, VA.: Human Resources Research Organization.

Katz, D. (1964). The Motivational Basis of Organizational Behavior. Journal of The Society for General Systems Research, 9(2), 131-146. 
Katz, D., Kahn, R. L. (1966). The Social Psychology of Organizations. Hoboken, NJ: Wiley.

Kee, H. M. D., Ansari, M., Aafaqi, R. (2004). Fairness Of Human Resource Management Practices, LeaderMember Exchange And Organızatıonal Commitment. Asian Academy of Management Journal, 9(1), 99120.

Lee, K., Allen, N. J. (2002). Organizational Citizenship Behavior and Workplace Deviance: The Role of Affect and Cognitions, Journal of Applied Psychology, 87(1), 132.

Liden, R. C., Maslyn, J. M. (1998). Multidimensionality of Leader-Member Exchange: An Empirical Assessment Through Scale Development. Journal of Management, (24), 43-72.

March, J. G., Simon, H. A. (1958). Organizations. New York: John Wiley \& Sons.

Meyer, J. P., Allen, N. J. (1997). Commitment in The Workplace. Thousand oaks Sage Publications, CA.

Meyer, J. P., Allen, N. J. (1984). Testing the "Side-Bet Theory" of Organizational Commitment: Some Methodological Considerations. Journal of Applied Psychology, 69(3), 372-378.

Meyer, J. P., Herscovitch, L. (2001). Commitment in the Workplace: Toward a General Model. Human Resource Management Review, 11, 299-326.

Mowday, R. T., Porter, L. W., Dubin, R. (1974). Unit Performance, Situational Factors, and Employee Attitudes in Spatially Separated Work Units. Organizational Behavior and Human Performance, 12(2), 231-248.

Podsakoff, P. M., Mackenzie, S. B., Moorman, R. H., Fetter, R. (1990). Transformational Leader Behaviours and Their Effects on Followers' Trust in Leader, Satisfaction and Organizational Citizenship Behaviours. Leadership Quarterly, 1, 107-142.

Rioux, S. M., Penner, L. A. (2001). The Causes of Organizational Citizenship Behavior: A Motivational Analysis. Journal of Applied Psychology, 86(6), 1306.

Schriesheim, C. A., Castro, S. L., Cogliser, C. C. (1999). Leader-Member Exchange (LMX) Research: A Comprehensive Review of Theory, Measurement, and Data-Analytic Practices. Leadership Quarterly, 10(1), 66-76.

Smith, C. A., Organ, D. W., Near, J. P. (1983). Organizational Citizenship Behavior: Its Nature and Antecedents. Journal of Applied Psychology, 68(4), 653-663.

Steers, R. M. (1977). Antecedents and Outcomes of Organizational Commitment. Sage Publications, 22(1), 46.

Şahin, F., Gürbüz, S. (2018). Sosyal Bilimlerde Araştırma Yöntemleri Felsefe Yöntem-Analiz (5. Baskı). Ankara: Seçkin Yayıncıllk.

Tongur, A. (2011). Organizational Support, Organizational Citizenship Behavior, and Perceived Performance: Analysis of Crime Scene Investigation Units of Turkish National Police (Yayınlanmamış Doktora Tezi). University of Central Florida, Florida.

Tutar, H. (2016). Örgütsel Davranış (Örgüt Teorileri ve Çă̆daş Yaklaşımlar Açısından), 1. Baskı, Ankara: Detay Yayıncilik.

Wolowska, A. (2014). Determinants of Organizational Commitment. Human Resources Management $\mathcal{E}$ Ergonomics, 8(1), 129-130.

Yorgancıŏ̆lu Tarcan, G., Yeşilaydın, G., Karahan, A. (2019). Örgütsel Bağlllık ve Örgütsel Vatandaşlık Davranışının İncelenmesi: Sağlık Çalışanları Üzerine Bir Araştırma. Hacettepe Sağlık İdaresi Dergisi, 22(1), 157-180.

Yorulmaz, A., Çelik, S. (2016). İlkokul Öğretmenlerinin Örgütsel Bağlllık, Örgütsel Sinizm ve Örgütsel Vatandaşlık Davranışları Arasındaki İlişki. Kalem Ĕ̆itim ve İnsan Bilimleri Dergisi, 6 (1), 161-193. 